\title{
Effectiveness of Career Service Information on Student's Motivation to Pursue Higher Education in Madrasah Aliyah Negeri Jeuram
}

\author{
Desi Arliani* \\ Graduate School \\ Universitas Negeri Yogyakarta \\ Yogyakarta, Indonesia \\ desiarlini.2018@student.uny.ac.id*
}

\author{
Muh Farozin \\ Guidance and Counseling Department \\ Universitas Negeri Yogyakarta \\ Yogyakarta, Indonesia \\ farozin@uny.ac.id
}

\begin{abstract}
This study aimed to see whether the career information services effectively to the motivation to continue on to college. This research is an experimental research to design a one-group pre-test post-test. The technique used in this study is the scale of motivation to continue on to college. This study involves a population of 130 students, in which 30 sample students were obtained using purposive random sampling. Analysis was conducted using paired t-test using SPSS version 22. The results showed that there were significant differences between student's motivation to pursue higher education before and after career information services was given $(8.720<$ $0,05)$. It is thus effective career information services provided to the students as a motivation to continue on to college. Service career information is essential given to students to provide insight to students related to education in college, not just the information that students get but also understanding and equip students with the knowledge and information that is useful for planning further education and career planning in the future front.
\end{abstract}

Keywords -motivation, career information service

\section{INTRODUCTION}

A college education is further education of upper secondary education, the role of a college education is a very important role to create and shape students to be individuals who have sufficient ability in building an intelligent nation and character. Continuing education to college would have to be based on the encouragement of the individuals themselves, a boost in the form of motivation. Motivation is a reason why people think, behave and have the feeling the way they do and emphasize the activation and direction of the individual's own behavior [1]

Rohman added that the motivation can be regarded as a set of driving forces that exist within the individual that can cause a reaction in the form of learning and motivation to ensure continuity of learning activities and provide direction on the activity or activities undertaken so that the objectives of the activity or activities undertaken to achieved [2]. Motivation comes from within the individual force that drives and directs the learning objectives. Motivation affects the individual spirit or students in the teaching and learning process in schools. Learning as a process of change in behavior after the individual or the students to follow the learning activities that occurred through a series of experiences that lead people to think and behave in the new.

According Berstain say that education is obtained not only in formal education, but education can also be obtained through non-formal education. Higher education is secondary education consisting of a diploma, undergraduate, graduate and doctoral organized by higher education [3]. According Sudarman learn in college is an adult education, which in living and motivation to pursue higher education requires not only contained prestige, fun, earn pocket money, free associating and free to choose. But a college education is the beginning of a journey to pioneer the future aspired [4]. Therefore, continuing education to higher education should be based on the motivation and interest of students because of the motivation and interest of the learner will influence the learning outcomes of students later. It is thus the interest and motivation of students to continue their education to higher education needs to be improved and developed.

But in reality, the results of a preliminary study conducted by researchers based on data from the teacher part kepeserta upbringing, that most students class XII Madrasah Aliyah Jeuram not continue their education to college with some consideration of the limited cost, lack of motivation, and lack of information given by the teacher career guidance and counseling as well as a lack of understanding of students related study choices in higher education. Therefore, guidance and counseling teachers are expected to be able to provide encouragement and motivation for students to continue their education to a higher level in accordance with the abilities and talents of its interests.

The phenomenon of low motivation of Madrasah Aliyah Jeuram students in continuing education to college is one of the effects of the implementation of guidance and counseling services are still less than optimal. In response to the problems it is necessary given the career information service about college information, the kinds of jobs and a variety of career-related information. Through a career information service students are expected to have an understanding associated with a career in higher education to encourage and motivate students to continue their education to a higher level. 
Career information service is a service in guidance and counseling given by a counselor or guidance and counseling teacher to a students to accept and understand the various career related information that can be taken into consideration and career decision making by students [5]. Sukardi added, career information service is the guidance that can provide benefits and a big influence on students and parents in determining and deciding a career that will be selected based on all the information received from the activities of students guidance or career information services [6]. While the career information is one of the tools used to assist students in understanding all forms of employment, education and the world of work [7].

Slameto argued that for the purpose of career information; a) understand the characteristics of yourself, such as interests, skills, values and personality traits and can identify occupations that match your personality, b) can distinguish several areas of life, such as the potential contributions, the nature of the nature of the work da demands of work in the field of work that will selected, c) identify areas of existing jobs, good jobs that are immediately and work that is going to come and assess whether these jobs have the possibility to choose for a particular job, d) identify a range of decisions that must be made in achieving the goals that have been set, e) selecting the type and area of work and study and understand the work in depth, and f) be able to choose education and training with the objective established career or job related. Therefore, the purpose of career information service in this study is able to see and assess the characteristics of the individual self, knowing the various types of work that can be selected in accordance with its potential and can plan a career in the future [8].

Career information services can be provided by using several methods in information services such as; through lectures that can be done by anyone who has adequate information in providing all forms of information needed, through discussions that can be done by teachers and students who have a lot of information and can be given to individuals who need it, through media that can be used in providing information that is, it can be in the form of pictorial media, written media, posters, and other electronic media, through field trips that can support the development of attitudes towards education and employment, through manuals such as college entry manuals and workshop manuals for employees, and through career conferences such as carried out by the education office and educational institutions to provide information on educational programs and jobs that can be followed by students [9].

As in Ismadi's research information about career services using effective e-learning, techniques are given to students to strengthen students in choosing careers. The product developed in his research is to develop e-earning learning models that can be accessed by students through the internet network. The material or topics presented are about talents and interests, values, personal abilities, motivation, further information, leadership information, career preparation, and career choices [10]. So in the research conducted by researchers, career information services are provided using lecture, discussion and media poster methods that are equipped with selected materials suitable for the career and educational needs of students in higher education.

Basically, every individual is a unique creature and in handling problems experienced by individuals not be generalized. Then the materials provided to students should be tailored to the problems and needs that occur or might occur to students so that treatment is given to the learner can actually feel its significance and more helpful in addressing the problems experienced by students [11]. Selection and determination of material that will be given to the students, as well as the selection of media information that is not based on the needs and problems experienced by students, will lead to the disinterest of students in following the activities of service, so the service activity becomes ineffective and conducive.

According to Tyler career information material provided to the students should have characteristic information is accurate and up to date. The accuracy in providing information with respect to information that can be reliably or dispersal. Accurate information is information that does not contain prejudice and conjecture, as well as information provided, comes from a trusted source and authority. The information contained should be informed, if the information contained is not the newest information or conjectural information, then the information can provide for the recipient's error and no information could be helpful [12]. A complete and accurate material very helps students understand the information conveyed and assist students in choosing and considering career choices. Students who follow the activities of career information service, not just get career information but also gain an understanding of himself concerning curry. And how students can develop themselves in the world of careers according to their abilities, talents, and interests.

The above statement is supported by Shakir with research results that prove that career information service delivery through ICT has a significant impact on the understanding of career and career decision making. Whereas before it provides ICT-based career information services many students are not able to determine and decide the career after graduating from high school. But after the service it provides career information, career-related learner comprehension increased significantly and the students are able to make decisions in his career [13]. A similar study conducted by Rosalin that aided information services career with a website can increase students' career planning significantly. The provided website provides information about college majors with the information available at various universities. Through a web-based career information services that can improve the career planning of students [14].

Career information services can be combined with a variety of techniques and methods that can support the success of the service, as research conducted Hijrah Eko Putro that by implementing services-based career field trip information to enhance understanding of the career of students [15]. The level of understanding of the career of students increased after the students participating in the career information services to the engineering field trip. Based on the results of the analysis showed that there was an 
average increase participant understanding upbringing career in the early evaluation questionnaire did service activities and a final evaluation after the given service activity and there are significant differences between before and after the services it provides career information to the engineering field trip.

Service career information is one of the efforts made to provide information related to careers to students in order to be able to know and understand the information office, the type of work and college information so that students can determine and decide the course at the college in accordance with the potential and work which will be chosen later. Rahmanian explained that career information services contributed $12.3 \%$ to the direction of career planning students [16].

Thus, it is necessary to conduct a study that tests whether effective career information services are provided to Madrasa Aliyah Negeri Jeram students in increasing motivation to continue their education to higher education by providing a Likert scale questionnaire to determine the level of student motivation.

\section{METHODS}

This research is a experimental research with one group pretest-posttest design with a population of 130 students. The sample in this study amounted to 30 students who were selected by purposive random sampling. Data collection techniques in this study are using a scale of motivation to continue education to tertiary institutions consisting of 30 questions with answer scores 1 to 4 . The instrument test results contained 21 items that were declared valid and 9 other items declared invalid. So the items used as instruments in the scale of this study amounted to 21 items. The data obtained were then analyzed using statistical tests or paired sample test t-tests with the help of SPSS version 22.

\section{III.RESULT AND DISCUSSION}

Result

The data in this study were analyzed using paired-sample t-test to see the difference before and after career information services treatment. The result is as follows:

Table 1. Paired Samples Statistics

\begin{tabular}{|c|c|c|c|c|}
\hline & $\mathrm{n}$ & Mean & $\begin{array}{c}\text { Std. } \\
\text { Deviation }\end{array}$ & $\begin{array}{l}\text { SE of } \\
\text { Mean }\end{array}$ \\
\hline $\begin{array}{l}\text { Pre- } \\
\text { test }\end{array}$ & $0^{3}$ & 60.53 & 9.730 & 1.776 \\
\hline $\begin{array}{l}\text { Post- } \\
\text { test }\end{array}$ & $0^{3}$ & 76.37 & 6.344 & 1.158 \\
\hline
\end{tabular}

The calculations shows that there are mean difference between student's motivation before and after career information services are provided and prove that career information services are effective in increasing motivation to continue their education to college in Madrasah Aliyah Negeri Jeuram's students. When viewed from the process of pretest, treatment, and posttest, career information services are quite effective in increasing motivation to continue education. For the initial stage, the pretest obtained on average with a total score of 60.53 and the posttest value obtained on average with a total score of 76.37. These results indicate a significant increase in students who have a low level of motivation in continuing education to college.

Test the effectiveness of career information services using parametric statistics through paired samples t-test. Calculations are performed using SPSS version 22.0, the results of paired samples test calculations show the results of the following significance.

Table 2. Paired Samples Test

\begin{tabular}{|l|c|c|c|c|c|}
\hline & Mean & $\begin{array}{l}\text { Std. } \\
\text { Deviation }\end{array}$ & $\begin{array}{l}\text { SE of } \\
\text { Mean }\end{array}$ & $\mathrm{T}$ & $\mathrm{df}$ \\
\cline { 1 - 5 } Pre-test & $\begin{array}{r}- \\
15.83\end{array}$ & 9.945 & 1.816 & $-8.720^{* * *}$ & 29 \\
\cline { 1 - 2 } $\begin{array}{l}\text { Post- } \\
\text { test }\end{array}$ & 3 & & & \\
\hline \multicolumn{2}{|l|}{$* * * \mathrm{p}<.001$} & & & \\
\hline
\end{tabular}

In the table 2 based on the results of data analysis, it is shown that $\mathrm{t}$ arithmetic $>\mathrm{t}$ table $(8,720>2,048)$ or $\mathrm{Sig}<0.05$ so that $H_{o}$ is rejected and $H_{a}$ is accepted [17]. So it can be concluded that there are differences before and after the provision of career information services to increase motivation to continue their education to universities in Madrasah Aliyah Negeri Jeuram. So thus that an effective career information service is provided to increase motivation to continue their education to tertiary students of Madrasah Aliyah Negeri Jeuram.

To conclude career information services are effective or not in increasing motivation to continue their education to tertiary institutions, the researchers based on the argument that has been built that is career information services said to be effective if respondents have increased motivation scores to continue their education to tertiary institutions after being given treatment in the form of career information services. Based on the results of the analysis there is an increase in the average score of students' motivations to continue their education to higher education in the pre-test and post-test questionnaire, so there is the influence of career information services to increase the motivation of students in continuing their education to college.

Motivation conditions for continuing education to tertiary education students of Madrasah Aliyah Negeri Jeuram, amounting to 30 students before being given career information services showed results namely; students with high categories amounted to 3 students, low categories numbered 13 students and very low categories numbered 14 students. After being given treatment in the form of career information services, the motivation for continuing education to tertiary institutions increased to a very high category of 2 students, a high category of 26 students and a low category of 2 students.

\section{Discussion}

The results of this study indicate that effective career information services are provided to students in increasing motivation to continue their education to higher education in Madrasah Aliyah Negeri Jeuram students and the calculation results show there are significant differences between before and after career information services are provided to students to increase motivation continuing education to tertiary institutions, meaning that after providing career 
information services the motivation of students increases significantly. This is reinforced by the theory put forward by Herminarto that motivation can occur if individuals have the desire and willingness to take actions that can achieve certain goals that have been formed [18].

The results of this study are in line with the results of research conducted by Deysin Morundu that career information services are effective in increasing the interest of students in continuing their studies to the Vocational Tourism Middle School in class IX students of SMP Negeri Satap Pantangolemba, Kab. Poso Career information service is one of the right types of services provided to students to help students to have a broad picture of the world of education in tertiary institutions and career information services can generate interest from within themselves to be able to continue their education to tertiary institutions. Besides that, students also know the purpose and benefits of continuing education in college [19].

Tatang Agus Pradana's research results show that students who obtain career information services using mind mapping techniques have increased career understanding higher than students who are not provided career information services with mind mapping techniques. The low level of knowledge of students will affect most of the future orientation of students. therefore by applying the mind mapping technique in conveying career information, it is expected that using mind mapping techniques can create new breakthroughs in improving students' career understanding [20]. This is in accordance with the statement of Richma Hidayati in her research that the purpose of career information services is to provide students with all information, knowledge, and understanding related to careers as a reference and consideration in choosing careers and education to a higher level [11].

Career information services are needed and become one important thing, as said by Winkel \& Sri Hastuti there are three things that underlie the importance of applying information delivery services in the whole program in planned guidance, namely: 1) students need all the information that can be a reference and material considerations in making decisions about further education and being equipped in the world of work, 2) knowledge and information that is accurate and relevant can help students to think rationally about career planning and all demands that exist in employment, 3) information in accordance with possessed understanding can make students aware of things that are consistent and things that can change according to the circumstances that occur [21]. Based on the explanation that has been described above, career information services are very instrumental in improving students' career understanding. This is reinforced by the results of research conducted by Hsuan-Fu Ho that career services are needed to assist students in determining careers and career services are also able to hone their students' skills in career planning. The results of this study indicate that students who receive career services have a different understanding related to careers with students who do not get career services [22]. That the content of career information itself is a service provided by the Guidance and Counseling teacher to individuals or students who are trying to help individuals to be able to plan, decide their career choices [11].

The results of Ilham Budisantoso's research show that the higher the motivation to learn, the higher the interest in continuing education to college. Vice versa if the motivation to learn is low then the interest in continuing education to college will also below. Not only motivation, but the educational background of parents also play an important role in increasing the interest of students to continue their education in college. The higher the level of parental education, the higher the interest of students in continuing education. Parents 'education level has a positive influence on students' career interests. In addition to factors of learning motivation and parental education level, it turns out that the peer factor can influence the interests of students to continue their education. The more interactions that students do in their peer groups, the greater the peer factor contributes to the students' interest in continuing their education to college [23]. This is consistent with what is said by Djaali that individual motivation can be influenced by several factors which include factors of interest, education of parents and peer groups [24]. So thus it can be said that motivation to learn can affect the interest in continuing education to college.

Career information services as expected can help students in the direction of career planning, but many parents still think that career problems are problems that only concern teachers at school. The role of parents in planning and choosing the right career is still less felt by the Guidance and Counseling teacher at school. This problem will increase when the Guidance and Counseling teacher understands and understands deeply about career development but does not collaborate in career planning matters and does not take actions that can direct students towards career understanding and career decision making. So thus, it has become the main task of Guidance and Counseling teachers in alleviating problems experienced by students, especially in this case career problems and further study. Student career planning is done by involving or collaborating with parents of students to jointly realize the optimal career development of students so that later students are able to make career decisions appropriately and independently [25].

Career planning for students is very effective if given career information service activities, where students are given the latest information and in accordance with the information needed by students, so that with career information services students can carefully plan career choices to be made. This is supported by the results of Novi Wahyu Hidayati's research that applies career information services for students 'career planning and shows the results that career information services have a positive influence on students' career planning. The implementation is that students are very enthusiastic about participating in the service activities provided. The information provided in these service activities is very helpful for students in knowing and understanding career information such as position information, types of positions in the world of work and educational information in universities [26]. 
Ramnia Dewi Putri's research results show that there are significant differences in the direction of students' career planning in the experimental group that is given treatment in the form of information services using a contextual teaching and learning approach with a control group that is only provided with conventional information services. So based on the results of the analysis conducted and the effectiveness test shows that information services with a contextual teaching and learning approach can improve the career planning direction of students in SMK. Implementation of information services using contextual teaching and learning approaches seems to be more effective in improving the career planning direction of students in SMK than conventional information services. However, conventional information services can also improve students' career planning, it's just that conventional information services do not provide high improvements such as information services using a contextual teaching and learning approach [27].

The implementation of career information service activities can be provided by using several methods and techniques that can support the success of service objectives, one of the methods used in providing career information services is as in the research conducted by Reza Muttaqin who carries out career information services assisted by interactive video and live modeling. The results of his research show that career information services assisted by interactive video and live modeling are effective in increasing the career understanding of student participants. Based on the results of the t-test analysis showed a significant increase in career understanding in the experimental group students who were given treatment in the form of interactive video-assisted career information services and in the other groups were given career information services with live modeling techniques. So that career information services assisted by interactive video and live modeling are effective for increasing students' career understanding [28].

Career information services when viewed from an Islamic perspective. What is a career in the Islamic view. This was explained in P. Nuraini's research that interventions using Islamic-based career information services can provide students with an understanding of how careers are in the Islamic view. Islamic-based career information services is a pattern that can be used by students as a form of implementation in career information service activities to enhance students' career aspirations towards a rules-based career that is applicable in the world and the rules of Allah SWT to obtain security and perceived benefits for themselves or for others [29].

While the results of Ibnu Athiyah's research that career information services with multimedia-assisted effectiveness to improve the career maturity of students based on hypothesis testing showed all indicators contained in aspects of career maturity of students experienced a significant increase after getting intervention in multimedia-assisted career information service. Field test results also prove that career information services using multimedia can be implemented well in SMA N 1 Paguyangan and Guidance and Counseling teachers have the motivation to participate in service activities undertaken and students also look enthusiastic in participating in career information service activities. multimedia [30].

Career information services are very important to be provided to students to create students who have an overview and understanding of the chosen career later. Not only students in secondary schools, but career information services are also important to be given to students in high school. As in Jason L. Brown's research, that college students are given career information services to develop graduates who have definite career goals. Colleges in Australia strive to provide tangible, evidence-based programs and services that can be measured to prepare graduates who are more focused on the world of work. This means that career information service programs really help individuals or students in understanding and choosing careers that are in accordance with their potential [31].

So overall and based on the findings of research in line with what researchers do prove that career information services are effective to be implemented in students, especially in increasing motivation to continue their education to higher education in Madrasah Aliyah Negeri Jeuram students.

\section{IV.CONCLUSION}

This study was conducted to determine the effectiveness of career information services to increase the motivation of XII Madrasah Aliyah Negeri Jeuram students in continuing their education to higher education through career information services. Then the results of the study indicate that effective career information services are provided to students and can increase the motivation of students to continue their education to higher education and prove effective. This is based on the acquisition of an average score of 60.53 before being given career information services and an average score of 76.37 after being given career information services. It is important for Guidance and Counseling teachers to better understand the conditions experienced by students and better direct students to increase motivation in continuing education to college because the motivation and interests of students largely determine student learning achievement in the future. In addition, the researchers are then expected to test career information services on other variables and different samples.

\section{ACKNOWLEDMENT}

The author would like to thank Mr. Moh Farozin for his guidance during data collection and for his advice and cooperation during the preparation of this article. The author also thanks to friends for the support given to the writer during the preparation of this article.

\section{REFERENCES}

[1] J. W. Santrock, Andolescence Perkembangan Remaja. Jakarta: Erlangga, 2003.

[2] N. Rohman, Psikologi Pendidikan. Yogyakarta: Teras, 2012

[3] L. Kaplan, Education and The Family. United State: Allyn and Bacon, 1992.

[4] P. Sudarman, Belajar Efektif di Perguruan Tinggi. Bandung: Rekatama Media, 2004 
[5] Prayitno, Panduan Kegiatan Pengawasan Bimbingan dan Konseling di Sekolah. Jakarta: Rineka Cipta, 2001.

[6] D. W. Sukardi, Pengantar Pelaksanaan Program Bimbingan dan Konseling di Sekolah. Jakarta: Rineka Cipta, 2000.

[7] D. W. Sukardi, Dasar-Dasar Bimbingan Karir di Sekolah. Surabaya: Usaha Nasional, 1989.

[8] Slameto, Proses Belajar Mengajar dalam Sistem Kredit Semester (SKS). Jakarta: Bumi Aksara, 1991.

[9] Prayitno dan E. Amti, Dasar-Dasar Bimbingan dan Konseling. Jakarta: Rineka Cipta, 1994.

[10] Ismadi, I. Tadjri dan W. Hardyanto, "Layanan Informasi Karir Teknik E-Learning Memantapkan Pilihan Karir Siswa Kelas X SMA,” Jurnal Bimbingan Konseling, vol. 2, 2012, pp. 61-66.

[11] R. Hidayati, "Layanan Informasi Karir Membantu Peserta Didik dalam Meningkatkan Pemahaman Karir," Jurnal Konseling GUSJIGANG, vol. 1, Juni 2015.

[12] Munandir, Program Bimbingan Karir di Sekolah. Jakarta: Departemen Pendidikan dan Kebudayaan, 1996.

[13] M. Syakir, A. Mahmud and, A. Achmad, "The Model of ICT-Based Career Information Service and Decision-Making Ability of LearnersStudents," International Journal of Environmental \& Science Education, vol. 11, 2016, pp. 5969-5979.

[14] H. Rosalin, Sunawan and, E. Purwanto, "Improving Career Plannng Using Website-Based Career information Service," Islamic Guidance and Counseling Journal, vol. 1, 2018, pp. 62-68

[15] H. E. Putro and, M. Japar, "Layanan Informasi Karir Berbasis Field Trip untuk Meningkatkan Pemahaman Karir Siswa," Indonesian Journal of Education Counseling, vol. 3, Agustus 2019, pp. 243-252.

[16] A. Rahmaniah, Kontribusi Layanan Informasi dan Layanan Penempatan/Penyaluran terhadap Perencanaan Karir Siswa, Thesis "unpublished" diterbitkan. Padang: Prodi S2 BK FIP UNP.

[17] Sugiyono, Metode Penelitian Kombinasi (Mixed Methods). Bandung: Alabet, 2012.

[18] H. Sofyan and, H. B. Uno, Teori Motivasi dan Aplikasi dalam Penelitian. Gorontalo: Nur Jannah, 2003.

[19] D. Morundu, A. Munir and, Nurwahyuni, "Efektivitas Layanan Informasi Karir dalam Meningkatkan Minat Melanjutkan Studi ke SMK Pariwisata pada Peserta Didik Kelas IX SMP Negeri Satap Pantangolemba Kab. Poso," Jurnal Konseling \& Edukasi, vol. 2, Juni 2017, pp. 59-68.
[20] T. A. Pradana, A. Sutoyo and, M. Japar, "The Effectiveness of Career Information Service with Mind Mapping Technique to Improve Student Occupational Knowledge," Jurnal Bimbingan Konseling, vol. 7, 2018, pp. 23-27.

[21] W.s. winkel and, S. Hastuti, Bimbingan dan Konseling di Institusi Pendidikan. Yogyakarta: Media Abadi, 2006.

[22] H. F. Ho, W. T. Huang and, T. L. Hu, "Enhancing the Quality of University Career Service in Taiwan: Perception on University Alumni," Contemporary Issues in Education Research-Third Quarter, vol. 11, 2018, pp. 113-120.

[23] I. Budisantoso, "Pengaruh Motivasi Belajar, Pendidikan Orang Tua dan Teman Sebaya terhadap Minat Melanjutkan Perguruan Tinggi bagi Peserta Didik Kelas XI SMA N 2 Klaten Tahun Ajaran 2015/2016," Jurnal Pendidikan dan Ekonomi, vol. 6, 2017, pp. 9-16.

[24] Djaali, Psikologi Pendidikan. Jakarta: Bumi Aksara, 2007.

[25] Afdal, M. Suya and, Uman, "Bimbingan Karir Kolaboratif dalam Pemantapan Perencanaan Karir Siswa SMA,"

[26] N. W. Hidayati, "Pengaruh Layanan Informasi Studi Lanjut Terhadap Karir Siswa,” Jurnal Edukasi, vol. 1, Juni 2014, pp. 94101.

[27] R. D. Putri, Neviyarni and, A. Irianto, "Efektivitas Layanan Informasi dengan Pendekatan Contextual Teaching and Learning dalam Meningkatkan Arah Perencanaan Karir Siswa SMK,” Ejournal UNP, vol. 4, September 2015, pp. 147-161.

[28] R. Muttaqin, Wagimin and, I. Tadjri, "Efektivitas Layanan Informasi Karir Berbantuan Video Interaktif dan Live Modelling untuk Meningkatkan Pemahaman Karir Siswa SMP,” Jurnal Bimbingan dan Konseling, vol. 2, 2017, pp. 174-179.

29] P. Nuraini, Tawil and, Subiyanto, "The Impat of Islamic-Based Career Information Service to Improve Career Aspirations of Students," Islamic Guidance and Counseling Journal, vol. 2, Januari 2019, pp. 26-32.

[30] I. Athiyah, I. Tadjri and, E. Purwanto, "Career Information Service Model Multimedia-Assisted for Increasing Students Career Maturity," Jurnal Bimbingan Konseling, vol. 1, 2014, pp. 16-21

[31] J. L. Brown, M. Healy, T. McCredie and, P. Mcllveen, "Career Service in Australian Higher Education: Aligning the Training of Practitioners to Comporary Practice," Journal of Higher Education Policy and Management, Juli 2019, pp. 1-16. 